\title{
Comparison of ultracentrifugation and polyethylene glycol precipitation for concentration of hepatitis B virus (HBV) DNA for molecular hybridisation tests and the relationship of $\mathrm{HBV}-\mathrm{DNA}$ to $\mathrm{HBe}$ antigen and anti- $\mathrm{HBe}$ status
}

\author{
D. SANYAL, G. KUDESIA and G. CORBITT* \\ Public Health Laboratory, Northern General Hospital, Herries Road, Sheffield and * Regional Virus Laboratory, Booth \\ Hall Childrens Hospital, Blackley, Manchester
}

\begin{abstract}
Summary. A ${ }^{32}$ P-labelled DNA probe was used to examine 50 hepatitis B surface antigen (HBsAg)-positive sera for the presence of hepatitis B virus (HBV) DNA. HBV-DNA was detected in all $21 \mathrm{HBeAg}$-positive samples, in one out of 21 anti-HBe-positive samples and in three out of eight $\mathrm{HBeAg}$ - and anti-HBe-negative samples. The results of this DNA hybridisation test correlated well with $\mathrm{HBeAg}$ status and could be used to determine infectivity in $\mathrm{HBeAg}$ - and anti-HBe-negative samples. Ultracentrifugation was marginally superior to polyethylene glycol precipitation for concentrating HBV-DNA from serum.
\end{abstract}

\section{Introduction}

The laboratory diagnosis of acute hepatitis $\mathbf{B}$ and detection of the chronic carrier state of hepatitis $B$ virus (HBV) depends upon serological tests. Hepatitis B surface antigen (HBsAg) is the first serological marker to appear in clinical infection ${ }^{1}$ and is followed by $\mathrm{HBeAg}$, a core-associated antigen that correlates closely with the number of virus particles, the presence of free $\mathrm{HBV}-\mathrm{DNA}$ in the serum, and relative infectivity. ${ }^{2}$ Antibody to $\mathrm{HBe}$ (anti-HBe) is not protective but is associated with lower infectivity.

The presence of HBV-DNA in serum can be detected with a ${ }^{32} \mathrm{P}$-labelled DNA probe. This was first done in 1980 with human and woodchuck hepatitis agents. $^{3}$ In previous studies in which molecular hybridisation methods were used to detect $\mathrm{HBV}-$ DNA in serum, ${ }^{4-6}$ close correlation was found between the presence of either $\mathrm{HBeAg}$ or the DNA polymerase enzyme, as measured by radio-immunoassay; DNA hybridisation was a more sensitive means of detecting complete virus particles as well as for monitoring antiviral therapy. ${ }^{7}$

Several techniques have been used for harvesting HBV-DNA from serum including pelleting the Dane particles by ultracentrifugation and precipitation with polyethylene glycol. Ultracentrifugation has proved to be superior to other methods of DNA extraction such as gel electrophoresis or direct application of serum samples to a nitrocellulose membrane because it gives a better autoradiography signal and minimises interference by serum components. ${ }^{8}$
The purpose of this study was to examine the correlation between the presence of HBV-DNA and $\mathrm{HBeAg}$ and anti-HBe status in $50 \mathrm{HBsAg-positive}$ serum samples, and to compare ultracentrifugation and polyethylene glycol precipitation methods of concentrating HBV-DNA in serum samples.

\section{Materials and methods}

\section{Serum samples}

Fifty HBsAg-positive serum samples were selected for examination; HBsAg was detected by enzymelinked immunosorbent assay (ELISA) (Wellcome Diagnostics). Some were from healthy blood donors and some from patients with acute or chronic hepatitis. All were tested for $\mathrm{HBeAg}$ and anti-HBe by ELISA with reagents from the Division of Microbiological Reagents and Quality Control (Central Public Health Laboratory, Colindale Avenue, London). Twenty-one samples gave positive results for $\mathrm{HBeAg}$ only, 21 for anti-HBe only and eight samples gave negative results for both. In addition, of the original 50 sera, 10 were paired sera from five patients who were initially $\mathrm{HBeAg}$-positive and then became anti-HBe-positive.

\section{DNA extraction and hybridisation}

HBV-DNA was extracted from virus particles obtained from the serum samples by ultracentrifugation or polyethylene glycol (PEG) precipitation.

Ultracentrifugation. The Dane (virus) particles were pelleted by centrifugation at $160000 \mathrm{~g}$ for $4 \mathrm{~h}$ at $4^{\circ} \mathrm{C}$. The pellet was resuspended in buffer for DNA extraction. 
Polyethylene glycol precipitation. To $100 \mu \mathrm{l}$ of serum, $50 \mu$ l of polyethylene glycol 6000 (BDH, Poole) $30 \%$ was added and left overnight at $4{ }^{\circ} \mathrm{C}$. The sample was then centrifuged for $30 \mathrm{~min}$ at $1000 \mathrm{~g}$ and the pellet was resuspended in buffer for DNA extraction.

The HBV-DNA was extracted and detected by dotblotting on a nitrocellulose membrane soaked in buffered salt solution (BSS; $3 \mathrm{M} \mathrm{NaCl}, 0.3 \mathrm{M}$ sodium citrate). Double stranded DNA in the sample was denatured by adding $200 \mu \mathrm{l}$ of $1 \mathrm{M} \mathrm{NaOH}$ to $100 \mu \mathrm{l}$ of virus suspension. The samples were transferred to the nitrocellulose membrane and neutralised by adding $200 \mu \mathrm{l}$ of $0.5 \mathrm{M} \mathrm{HCl}$ to each well of the dot-blot apparatus (BioRad, Hemel Hempstead). As a positive control, dilutions of an HBV-DNA standard (obtained from a pool of laboratory positive samples) were made at concentrations of $100 \mathrm{pg}, 10 \mathrm{pg}, 5 \mathrm{pg}, 1 \mathrm{pg}$ and $0.5 \mathrm{pg}$ and applied to the nitrocellulose membrane as above. The membrane was then baked at $80^{\circ} \mathrm{C}$ for $2 \mathrm{~h}$ after which it was treated to prevent non-specific binding by adding $15 \mathrm{ml}$ of skimmed milk $(0 \cdot 25 \% \mathrm{v} / \mathrm{v})$ in BSS and incubating overnight at $65^{\circ} \mathrm{C}$.

The DNA probe (kindly donated by Dr J. Monjardino, Royal Free Hospital, London) was labelled by the random priming method of Klenow. ${ }^{9}$ The specific activity of the labelled probe was measured in a scintillation counter and gave a value of $1.2 \times 10^{9} \mathrm{cpm} /$ pg of DNA. The probe was added to the nitrocellulose membrane with $8 \mathrm{ml}$ of skimmed milk $0.25 \%$ in BSS and left to hybridise overnight at $65^{\circ} \mathrm{C}$. After one low and one high stringency wash in BSS, the nitrocellulose membrane was overlayed with photographic film (Fuji $\mathrm{RXG}$ ) and held at $-70^{\circ} \mathrm{C}$ for $24 \mathrm{~h}$ before developing. The cut-off for positivity was a dot intensity greater than that of the $0 \cdot 5-\mathrm{pg}$ standard.

\section{Results}

A positive dot-blot result for HBV-DNA was obtained with 25 specimens after ultracentrifugation preparation and from 23 specimens after PEG precipitation. All $21 \mathrm{HBeAg}$-positive specimens gave positive dot-blot results for HBV-DNA after preparation by ultracentrifugation and 20 of them gave positive results after PEG precipitation. Only one of 21 anti-HBe-positive but $\mathrm{HBeAg}$-negative samples gave a positive dot-blot for HBV-DNA; this was from a sample prepared by ultracentrifugation. There was no noticeable difference in the intensity of autoradiography signals between dot-blots prepared from specimens harvested by ultracentrifugation and by PEG precipitation.

In the 10 paired serum samples from five patients who were initially $\mathrm{HBeAg}$-positive and then became anti-HBe-positive, the initial $\mathrm{HBeAg}$-positive samples gave positive dot-blot results for HBV-DNA and the anti-HBe-positive samples gave negative results for $\mathrm{HBV}-\mathrm{DNA}$ in each case.

\section{Discussion}

Our results show a strong positive correlation between the presence of HBV-DNA and $\mathrm{HBeAg}$, confirming previous studies. ${ }^{5,6,10}$ HBV-DNA was detected in samples prepared by ultracentrifugation from $21 \mathrm{HBeAg}$-positive sera. It would be reasonable to assume that the presence of HBV-DNA is responsible for the greater infectivity of $\mathrm{HBeAg}$-positive sera. There was also a strong negative correlation between the presence of anti-HBe and HBV-DNA. In only one sample was a small amount of HBV-DNA detected and this specimen had previously given only a low positive result in the anti-HBe ELISA.

Our results are consistent with the evidence that viral DNA disappears from the serum and becomes integrated into hepatocytes in anti-HBe-positive carriage $^{11}$ and that active virus replication does not occur in such circumstances. However, they differ from the results of previous studies which showed that a substantial proportion of patients with anti-HBe may have free HBV-DNA in their serum. ${ }^{6,10}$ It is possible that more anti-HBe-positive samples may have given an autoradiograph signal in the dot-blot analysis (albeit weakly) if the exposure time of the film had been prolonged to (e.g.) $48 \mathrm{~h}$. Furthermore, the number of specimens in our study was small. However, the overall correlation was well demonstrated in the

Table. Distribution of HBV-DNA-positive specimens prepared by ultracentrifugation or $\mathrm{PEG}$ precipitation in relation to $\mathrm{HBeAg}$ status

\begin{tabular}{l|ccc}
\hline HBeAg status & $\begin{array}{c}\text { Number of } \\
\text { samples } \\
\text { tested }\end{array}$ & $\begin{array}{c}\text { Number of samples that were } \\
\text { HBV-DNA positive after } \\
\text { preparation by }\end{array}$ \\
\cline { 2 - 4 } & & UCF & PEG \\
HBe Ag+ve & 21 & 21 & 20 \\
HBti-HBe+ve & 21 & 1 & 0 \\
Total & 8 & 3 & 3 \\
\hline
\end{tabular}

UCF, ultracentrifugation; PEG, polyethylene glycol precipitation. 
paired sera from five patients in which disappearance of $\mathrm{HBeAg}$ correlated with disappearance of $\mathrm{HBV}-$ DNA and with the appearance of anti-HBe.

The HBV-DNA probe was of particular use in determining the presence of viral DNA (and hence infectivity) in those patients whose sera gave negative results for both $\mathrm{HBeAg}$ and anti-HBe in ELISA. Some of these samples gave strong dot-blot reactions and might, therefore, be of high infectivity. Some patients may remain $\mathrm{HBeAg-negative} \mathrm{and} \mathrm{anti-HBe-negative}$ for some time and molecular hybridisation could be useful in separating them into potentially infectious and non-infectious groups.

Non-radioactive biotinylated DNA probes have been evaluated with a streptavidin-alkaline phosphatase conjugate ${ }^{12,13}$ but they are less sensitive than the ${ }^{32} \mathrm{P}$-labelled probe, ${ }^{14}$ although alkaline phosphatase may be as sensitive as the ${ }^{32} \mathrm{P}$-labelled probe. ${ }^{15}$ Non-

\section{References}

1. Hoofnagle JH, Seeff LB, Bales ZB, Gerety RJ, Tabor E. Serologic responses in HB. In: Vyas GN, Cohen SN, Schmid R (eds) Viral hepatitis. Philadelphia, Franklin Institute Press, 1978: 219-242.

2. Alter HJ, Seeff LB, Kaplan PM et al. Type B hepatitis: the infectivity of blood positive for $e$ antigen and DNA polymerase after accidental needlestick exposure. $N$ Engl J Med 1976; 295 : 909-913.

3. Cummings IW, Browne JK, Salser WA et al. Isolation, characterization and comparison of recombinant DNAs derived from genomes of human hepatitis B virus and woodchuck hepatitis virus. Proc Nat Acad Sci USA 1980; 77: $1842-1846$

4. Brechot C, Hadchouel M, Scotto J et al. Detection of hepatitis $B$ virus DNA in liver and serum: a direct appraisal of the chronic carrier state. Lancet 1981; 2: 765-768.

5. Weller IVD, Fowler MJF, Monjardino J, Thomas HC. Detection of HBV-DNA in serum by molecular hybridisation: a more sensitive method for the detection of complete HBV particles. J Med Virol 1983; 9: 273-280.

6. Scotto J, Hadchouel M, Hery C, Yvart J, Tiollais P, Brechot C. Detection of hepatitis B virus DNA in serum by a simple spot hybridization technique: comparison with results for other viral markers. Hepatology 1983; 3: 279-284.

7. Fowler MJF, Monjardino J, Weller IVD, Lok ASF, Thomas HC. Analysis of the molecular state of HBV-DNA in the liver and serum of patients with chronic hepatitis or primary liver cell carcinoma and the effect of therapy with adenine arabinoside. Gut 1984; 25: 611-618. radioactive probes have the advantage of greater safety and a longer shelf-life.

Preparation of samples by ultracentrifugation gave marginally better results than preparation by PEG precipitation. However, the difference in intensity of reactions between dot-blots prepared by the two methods was not sufficiently large to be of general practical significance in routine testing. Nevertheless, all $\mathrm{HBeAg}$-positive samples were $\mathrm{HBV}$-DNA positive after ultracentrifugation, but one was HBV-DNAnegative after PEG precipitation. Furthermore, in the only sample that was anti-HBe-positive and had detectable HBV-DNA, the HBV-DNA was detected in a sample prepared by ultracentrifugation; the sample prepared by PEG precipitation gave a negative dot-blot. However, PEG precipitation is cheaper and more convenient to perform, especially if a large number of samples are to be processed.

8. Thomas HC, Karayiannis $\mathrm{P}$, Fowler MJF, Monjardino J. Clinical uses of HBV-DNA assays. J Virol Methods 1985; 10: 291-294.

9. Feinberg AP, Vogelstein B. A technique for radiolabeling DNA restriction endonuclease fragments to high specific activity. Anal Biochem 1983; 132: 6-13.

10. Lieberman HM, LaBrecque DR, Kew MC, Hadziyannis SJ, Shafritz DA. Detection of hepatitis B virus DNA directly in human serum by a simplified molecular hybridization test: comparison to $\mathrm{HBeAg} /$ anti-HBe status in $\mathrm{HBsAg}$ carriers. Hepatology 1983; 3: 285-291.

11. Brechot C, Pourcel C, Louise A, Rain B, Tiollais P. Presence of integrated hepatitis B virus DNA sequences in cellular DNA of human hepatocellular carcinoma. Nature 1980; 286: 533-535.

12. Quibriac $\mathbf{M}$, Petitjean J, Novel $\mathbf{M}$, Freymuth F. Nonradioactive spot hybridization test for detection of hepatitis B virus DNA in serum. Ann Inst Pasteur Virol 1987; 138: 377-384.

13. Saldanha J, Karayiannis P, Thomas HC, Monjardino JP. Use of biotinylated probes in serum hepatitis B virus DNA detection. J Virol Methods 1987; 16: 339-342.

14. Donovan RM, Bush CE, Peterson WR et al. Comparison of non-radioactive DNA hybridisation probes to detect human immunodeficiency virus nucleic acids. Mol Cell Probes 1987; 1: 359-366.

15. Manzin A, Pauri P, Bagnarelli P et al. Detection of hepatitis B virus DNA in serum using synthetic non-radioactive oligonucleotides. J Clin Pathol 1989; 42 : 1206-1210. 